\title{
In Situ Localization of Barley Yellow Dwarf Virus-PAV 17-kDa Protein and Nucleic Acids in Oats
}

\author{
Petra H. Nass, Leslie L. Domier, Birute P. Jakstys, and Cleora J. D’Arcy
}

First, second, and fourth authors: University of Illinois, Department of Crop Sciences, University of Illinois at Urbana-Champaign, Urbana 61801; second author: United States Department of Agriculture, Agricultural Research Service, Crop Protection Research Unit, 1102

South Goodwin Avenue, Urbana, IL 61801; and third author: College of Veterinary Medicine, Urbana, IL 61801.

Current address of P. H. Nass: Johns Hopkins Bayview Medical Center, Department of Surgery, 4940 Eastern Avenue, Baltimore, MD 21224. Accepted for publication 22 June 1998.

\begin{abstract}
Nass, P. H., Domier, L. L., Jakstys, B. P., and D’Arcy, C. J. 1998. In situ localization of barley yellow dwarf virus-PAV $17-\mathrm{kDa}$ protein and nucleic acids in oats. Phytopathology 88:1031-1039.

Barley yellow dwarf virus strain PAV (BYDV-PAV) RNA and the 17-kDa protein were localized in BYDV-PAV-infected oat cells using in situ hybridization and in situ immunolocalization assays, respectively. The in situ hybridization assay showed labeling of filamentous material in the nucleus, cytoplasm, and virus-induced vesicles with both sense and antisense nucleic acid probes, suggesting that the filamentous material found in BYDV-PAV-

plasm. The $17-\mathrm{kDa}$ protein was associated with filamentous material in the cytoplasm, nucleus, and virus-induced vesicles. The labeling densities observed using antibodies against the $17-\mathrm{kDa}$ protein were similar in the nucleus and cytoplasm. No labeling of the $17-\mathrm{kDa}$ protein was observed in plasmodesmata, but filaments in the nuclear pores occasionally were labeled. Since BYDV-PAV RNA and 17-kDa protein colocalized within infected cells, it is possible that single-stranded viral RNA is always associated with the $17-\mathrm{kDa}$ protein in vivo. The $17-\mathrm{kDa}$ protein may be required for viral nucleic acid filaments to traverse the nuclear membrane or other membrane systems.
\end{abstract} infected cells contains viral RNA. BYDV-PAV negative-strand RNA was detected before virus particles were observed, which indicates that RNA replication is initiated before synthesis of viral coat protein in the cyto-
Additional keywords: electron microscopy, luteovirus.
Barley yellow dwarf viruses (BYDVs) are members of the plant virus family Luteoviridae. They are obligately transmitted from infected to healthy plants by aphid vectors. Viruliferous aphids inject the virus into the phloem of healthy plants during the feeding process $(8-10)$, and the viruses remain restricted to the phloem tissues $(6,17)$. The cytopathological changes induced by BYDV strain PAV in phloem tissues have been divided into three phases: early, intermediate, and late $(11-13,17)$. At the beginning of the early phase, densely staining material appears in the plasmodesmata, followed by an electron-opaque substance and filaments, either free or within single-membrane-bound vesicles, in the host cytoplasm. At the end of the early phase, filaments are visible in the nuclear pores. During the intermediate phase of infection, the nuclear outline becomes distorted and massive clumping of heterochromatin begins. Only in the late phase can viral particles be seen in the cytoplasm and later in the nucleus, after much of the nuclear membrane has disintegrated. Based on the length and diameter of the filaments, Gill and Chong (13) suggested that the filaments seen in the early phase contain viral RNA. However, they were unable to remove the filaments from their preparations by RNAse treatment and suggested that the viral nucleic acids might be protected from RNAse digestion by viral or host proteins. Filamentous materials have been observed in association with virusinduced vesicular structures in the cytoplasm of host cells infected with viruses of other taxonomic groups. In several cases, viral replication has been associated with these structures $(5,14,19,20)$.

Corresponding author: L. L. Domier; E-mail address: 1-domier@uiuc.edu

Publication no. P-1998-0806-01R

This article is in the public domain and not copyrightable. It may be freely reprinted with customary crediting of the source. The American Phytopathological Society, 1998.
The protein product of the luteovirus open reading frame 4 (ORF 4), a 17-kDa protein, has been proposed to be involved in several different events in the BYDV life cycle. ORF 4 is nested entirely within ORF 3, which encodes the 22-kDa viral coat protein (CP) (22). The 17-kDa protein has been cited as potentially functioning as a genome-linked viral protein $(\mathrm{VPg})(23,25)$. However, recent results demonstrating that the $17-\mathrm{kDa}$ proteins of beet western yellows virus (BWYV) (30) and BYDV (24) are not required for replication suggest that the VPg hypothesis is probably incorrect. Chay et al. (3) have shown that while BYDV mutants do not express the 17-kDa protein replicate well in isolated protoplasts, they fail to infect whole plants, suggesting that the $17-\mathrm{kDa}$ protein may have a role in the movement of BYDV within the phloem.

Until recently, the long-distance movement of phloem-limited viruses like luteoviruses and geminiviruses was thought to be entirely passive and independent of viral gene expression $(1,15)$. However, geminiviruses express two proteins that are required for longdistance movement and for movement of single-stranded viral DNA into and out of the nuclei $(27,28)$. The $17-\mathrm{kDa}$ protein of potato leaf roll virus (PLRV) has been shown to bind nonspecifically to single-stranded (ss) RNA and DNA in vitro (35) and to be associated with plasmodesmata in PLRV-infected plants (31). Tacke et al. (35) suggested that the 17-kDa protein might serve to stabilize viral nucleic acids in vivo and, hence, may be responsible, at least in part, for the RNase insensitivity observed by Gill and Chong (13). These features give the product of the luteovirus ORF 4 many of the characteristics associated with movement proteins like the tobacco mosaic virus $30-\mathrm{K}$ protein, including the ability to bind singlestranded nucleic acids and to bind to plasmodesmata $(4,37)$.

To determine if the filaments observed in infected oat cells contain BYDV RNA and to elucidate the association of the 17-kDa product of ORF 4 with BYDV RNA, virus-induced structures and host cell components, the intracellular distributions of BYDV-PAV 
minus- and plus-strand RNAs, and 17-kDa protein were determined in infected oat tissue using in situ hybridization and immunogold assays, respectively.

\section{MATERIALS AND METHODS}

Virus, vector, and hosts. An Illinois vector-nonspecific isolate of BYDV (PAV-IL) was used in these studies. Oats (Avena byzantina cv. Coast Black) were grown and inoculated with viruliferous aphids (Rhopalosiphum padi L.) as described previously (26).

Sample preparation for electron microscopy. Tissue samples for electron microscopy were prepared by conventional methods as described previously (26) or by freeze substitution. For freeze substitution, five tissue samples were collected from the midrib of inoculated primary leaves of infected plants and the corresponding leaves of noninoculated controls at $1,2,3,4,5$, and 10 days postinoculation (dpi). Leaf samples were sliced into $1-\mathrm{cm}^{2}$ pieces that were subsequently immersed in the primary fixative $(3.5 \%$ paraformaldehyde, $0.5 \%$ glutaraldehyde, and $50 \mathrm{mM}$ sodium cacodylate, $\mathrm{pH}$ 7.0). After approximately $1 \mathrm{~h}, 1-\mathrm{mm}^{2}$ pieces were cut and incubated in the primary fixative overnight at $4{ }^{\circ} \mathrm{C}$. Tissue pieces were transferred into cryoprotectant solution $(1.8 \mathrm{M}$ sucrose and $50 \mathrm{mM}$ sodium cacodylate, $\mathrm{pH} 7.0) 2 \mathrm{~h}$ prior to freezing. Approximately 20 sections were transferred onto each copper grid (300 mesh, 3-mm; Electron Microscopy Sciences, Ft. Washington, PA), and cryoprotectant solution was carefully removed from the surface of the plant material and the copper grids. The copper grids were plunged rapidly into liquid nitrogen-cooled propane from which they were subsequently transferred into a metal basket within the liquid nitrogen reservoir. This process

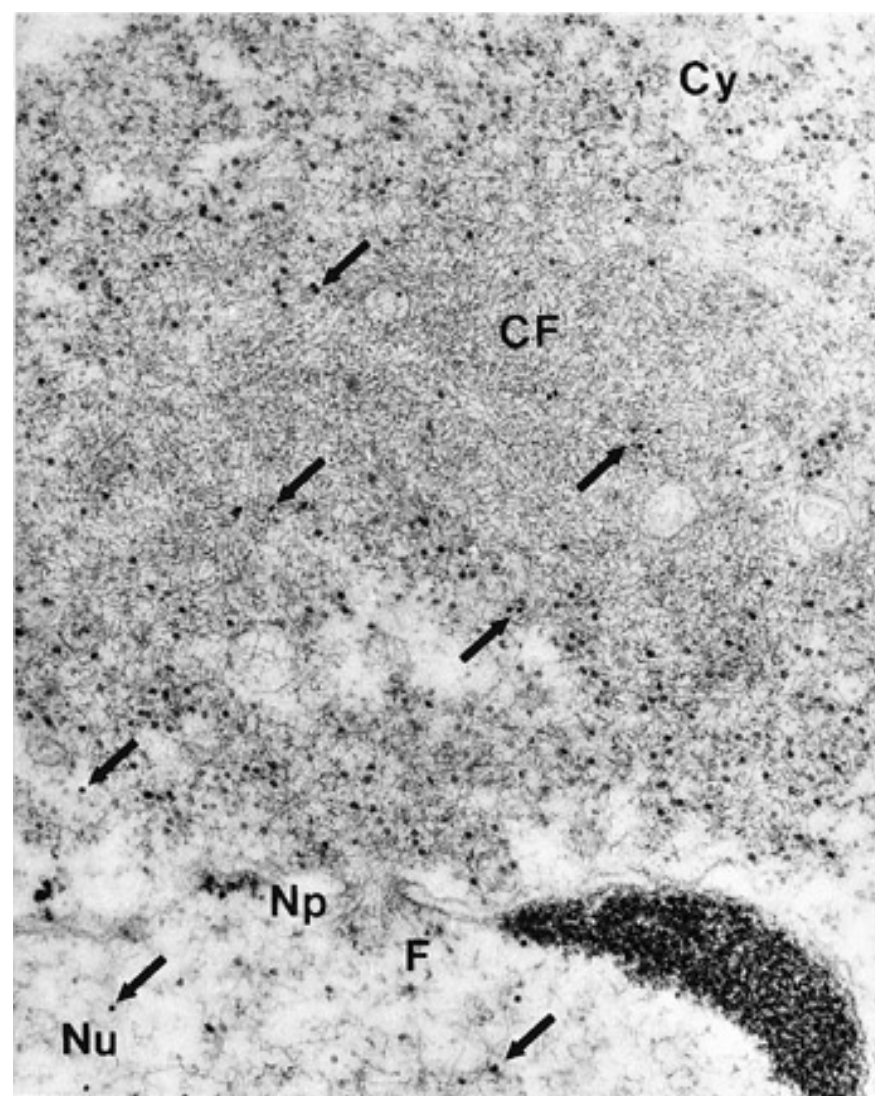

Fig. 1. The presence of filaments was a common cytopathological change in barley yellow dwarf virus strain PAV-infected oat phloem cells 2 to 4 days postinoculation. Filaments $(\mathrm{F})$ were typically seen first in the cytoplasm $(\mathrm{Cy})$ and later in the nucleus $(\mathrm{Nu})$ and nuclear pores (NP). Large areas of condensed filaments $(\mathrm{CF})$ were often seen in the cytoplasm during later stages of infection. The $17-\mathrm{kDa}$ protein was detected (arrows indicates gold label) in association with filaments first in the nucleus and later in the cytoplasm of infected cells. $\times 42,000$. was continued for all samples. At the end of this process, the baskets that contained the grids were transferred into a Reichert freeze substitution unit (Reichert, Vienna). The plant material was freeze-substituted with methanol that contained $1 \%$ osmium tetroxide for $72 \mathrm{~h}$ at $-80^{\circ} \mathrm{C}$, and then slowly brought up to room temperature at a rate of $3^{\circ} \mathrm{C} / \mathrm{h}$. Tissue pieces were then infiltrated with acetone and embedded in a Medcast/ Spurr resin mixture $(1: 1$; Ted Pella, Redding, CA). The resulting blocks were cured at $70^{\circ} \mathrm{C}$ for $20 \mathrm{~h}$. Sections $(80 \mathrm{~nm})$ were cut with a Reichert Ultracut S ultramicrotome (Reichert) and used for in situ localization experiments.

Immunolocalization of BYDV-encoded proteins. Antiserum to BYDV-PAV particles has been described previously (26). To produce antiserum to the $17-\mathrm{kDa}$ protein, a DNA segment corresponding to ORF 4 was amplified by polymerase chain reaction and inserted into pGEX-2T (Pharmacia Biotechnology, Inc., Piscataway, NJ) (33). ORF 4 was expressed in Escherichia coli as a fusion to glutathione-S-transferase, purified by affinity chromatography (33), and injected into New Zealand white rabbits to produce an antiserum specific for the 17-kDa protein. Antisera (diluted 1:100) were cross-adsorbed with sap of noninoculated oat plants and used to label 30 grids of BYDV-infected plant material from each sampling interval, as described previously (26).

Preparation of hybridization probes. A plasmid, pPAV410, containing a cDNA copy of BYDV-PAV-IL RNA between bacteriophage $\mathrm{T} 3$ and $\mathrm{T} 7$ promoters was used to transcribe strand-specific biotin-labeled probes for BYDV-PAV RNA (7). Transcription reactions using T3 RNA polymerase produced biotinylated probes specific for plus strands. Transcription reactions using T7 RNA polymerase produced biotinylated probes specific for minus strands. In vitro transcription reactions $(50 \mu \mathrm{l})$ were incubated for $30 \mathrm{~min}$ at $37^{\circ} \mathrm{C}$ and contained $5 \mu \mathrm{g}$ of cleaved pPAV $410 \mathrm{DNA} ; 40 \mathrm{mM}$ Tris, $\mathrm{pH} 8.0 ; 8 \mathrm{mM} \mathrm{MgCl} 2 ; 2 \mathrm{mM}$ spermidine; $50 \mathrm{mM} \mathrm{NaCl} ; 30 \mathrm{mM}$ dithiothreitol; 1 U of RNAse-Block II (Stratagene, Inc., La Jolla, CA); $10 \mathrm{U}$ of T3 or T7 RNA polymerase; and $1 \mathrm{mM}$ each of ATP, CTP, GTP, and biotinylated UTP (Life Technologies, Inc., Gaithersburg, MD).

In situ hybridization. All steps were performed in autoclaved and baked glass petri dishes. To avoid evaporation of solutions at higher incubation temperatures, petri dishes were kept in a moist chamber. As in the immunolocalization studies, about 20 ultrathin sections were placed on each carbon-coated Formvar nickel grid. Sections were pretreated with protease $\mathrm{K}(10 \mathrm{mg} / \mathrm{ml}$ in $10 \mathrm{mM}$ Tris- $\mathrm{NaOH}, \mathrm{pH} \mathrm{7.4}$, and $2 \mathrm{mM} \mathrm{CaCl}$ ) for $60 \mathrm{~min}$ at $37^{\circ} \mathrm{C}$, and then incubated for $20 \mathrm{~min}$ at $42^{\circ} \mathrm{C}$ on 50 - $\mu$ d droplets of prehybridization solution $(50 \%$ formamide, $6 \times$ SSPE $[20 \times$ SSPE is $3.0 \mathrm{M} \mathrm{NaCl}$, $0.2 \mathrm{M}$ sodium phosphate, and $0.02 \mathrm{M}$ EDTA, $\mathrm{pH} 7.4], 0.1 \%$ bovine serum albumin, $0.1 \%$ Ficoll, $0.1 \%$ polyvinylpyrolidone, and $200 \mu \mathrm{g}$ of yeast RNA per $\mathrm{ml}$ ). The temperature was kept constant using a water bath. Grids were then transferred onto 50- $\mu$ d droplets of hybridization solution (1 ng of biotinylated minus- or plus-strand in vitro transcript probe in $500 \mu \mathrm{l}$ of prehybridization solution) and allowed to hybridize at $42^{\circ} \mathrm{C}$. After $5 \mathrm{~h}$, the following steps were all performed at room temperature. Grids were removed and washed four times for $5 \mathrm{~min}$ on $25-\mu \mathrm{l}$ droplets of $5 \times \mathrm{SSC}(20 \times \mathrm{SSC}$ is $3.0 \mathrm{M}$ $\mathrm{NaCl}$ and $0.3 \mathrm{M}$ sodium citrate, $\mathrm{pH} 7.0$ ), once for $15 \mathrm{~min}$ on $0.1 \times$ SSC, and three times for $5 \mathrm{~min}$ on $2 \times$ SSC. Nonspecific binding sites were then blocked with $3 \%$ bovine serum albumin in TBSTween (100 mM Tris-NaOH, $150 \mathrm{mM} \mathrm{NaCl}$, and $0.05 \%$ Tween-20, $\mathrm{pH}$ 7.5) for $5 \mathrm{~min}$. Hybridized DNA probes were detected with goat anti-biotin antibodies conjugated to 10 -nm-diameter gold particles (Ted Pella, Redding, CA) at a 1:25 dilution in TBS-Tween. After $30 \mathrm{~min}$, sections were washed twice in droplets of TBS-Tween and twice in distilled water. Sections were stained for $60 \mathrm{~min}$ on droplets of $4 \%$ aqueous uranyl acetate and viewed with an Hitachi H-600 transmission electron microscope (Nissei Sangyo America, Ltd., Mountainview, CA) at $75 \mathrm{kV}$. Thirty grids were analyzed from each sample. 


\section{RESULTS}

Ultrastructure. BYDV-PAV-induced cytopathological changes similar to those reported by others $(11-13,17)$ were observed in this study. Filamentous material was first seen in the cytoplasm of infected phloem parenchyma and phloem companion cells as early as $1 \mathrm{dpi}$. Typically, filaments were abundant in the cytoplasm at 3 to $4 \mathrm{dpi}$, where they often formed circular aggregates with diameters of up to several hundred nanometers (Fig. 1). These aggregates will be referred to as condensed filamentous material. Filaments at the outer edges of these aggregates were frequently associated with ribosomes and virus particles. In only 1 out of over 30 samples were large amounts of filaments observed in the nucleus at $1 \mathrm{dpi}$ when no filaments were visible in the cytoplasm of infected cells. In all other samples, filaments were observed in the nucleus and in the nuclear pores at 2 to $4 \mathrm{dpi}$. At late stages of infection ( $>5 \mathrm{dpi}$ ), cells were often completely filled with virus particles and condensed filamentous material.

Localization of 17-kDa protein. Using an antiserum raised against recombinant $17-\mathrm{kDa}$ protein, gold labeling was observed

TABLE 1. Label densities for the 17- and 22-kDa proteins of barley yellow dwarf virus strain PAV-IL associated with filaments in the nucleus and cytoplasm and condensed filaments in the cytoplasm

\begin{tabular}{llllc}
\hline & \multicolumn{2}{c}{ Nucleus } & & \multicolumn{2}{c}{ Cytoplasm } \\
\cline { 2 - 3 } & Filaments & & Filaments & Condensed filaments \\
\hline $17 \mathrm{kDa}$ & $7.7^{\mathrm{a}}(4.4)^{\mathrm{b}}$ & & $8.8(4.9)$ & $3.6(0.49)$ \\
$22 \mathrm{kDa}$ & $1.4(1.1)$ & & $5.1(3.6)$ & 0.0 \\
Control & 0.0 & & 0.0 & 0.0 \\
\hline
\end{tabular}

${ }^{a}$ Gold particles/square micrometer; values are averages from three experiments in which five independent micrographs, each containing four to five cells, were examined.

${ }^{\mathrm{b}}$ Values in parentheses are standard deviations.

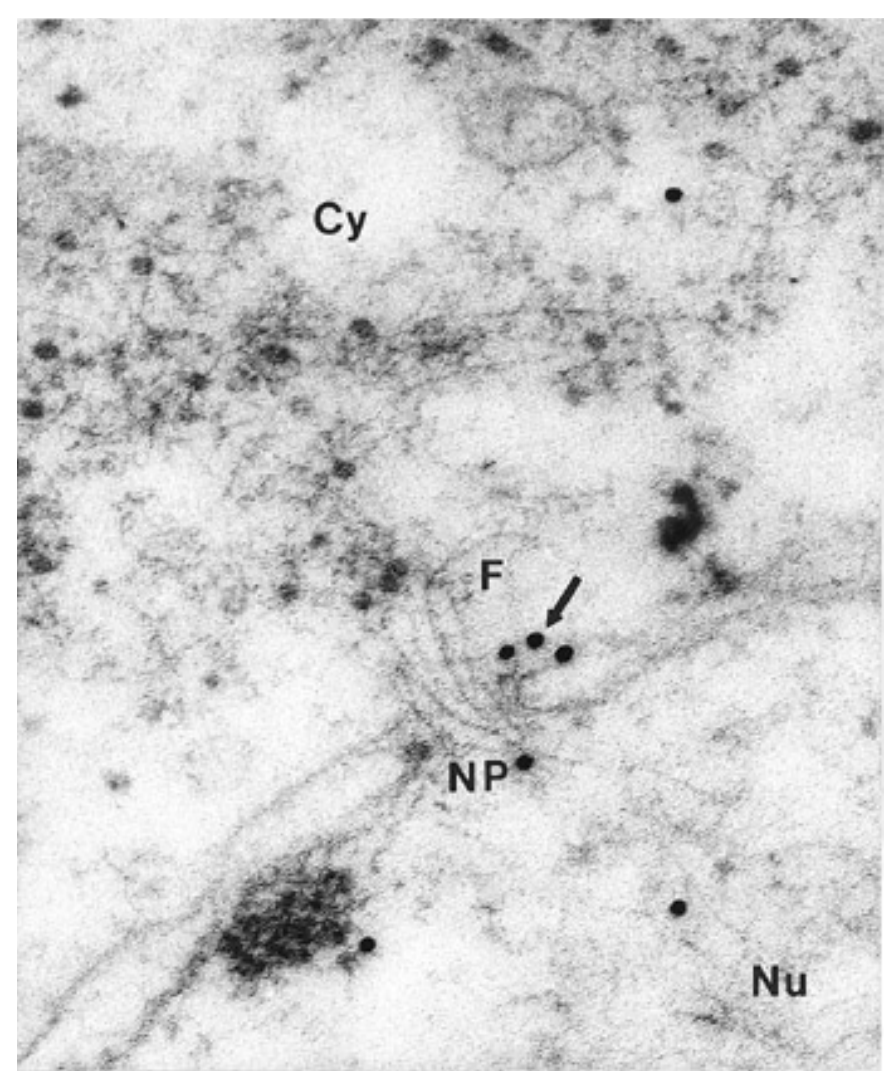

Fig. 3. Filaments $(\mathrm{F})$ were observed in nuclear pores $(\mathrm{NP})$ of barley yellow dwarf virus strain PAV-infected oat phloem cells 2 to 4 days postinoculation. The $17-\mathrm{kDa}$ protein (arrow indicates gold label) was occasionally associated with these filaments. $\mathrm{Cy}=$ cytoplasm and $\mathrm{Nu}=$ nucleus. $\times 138,000$.
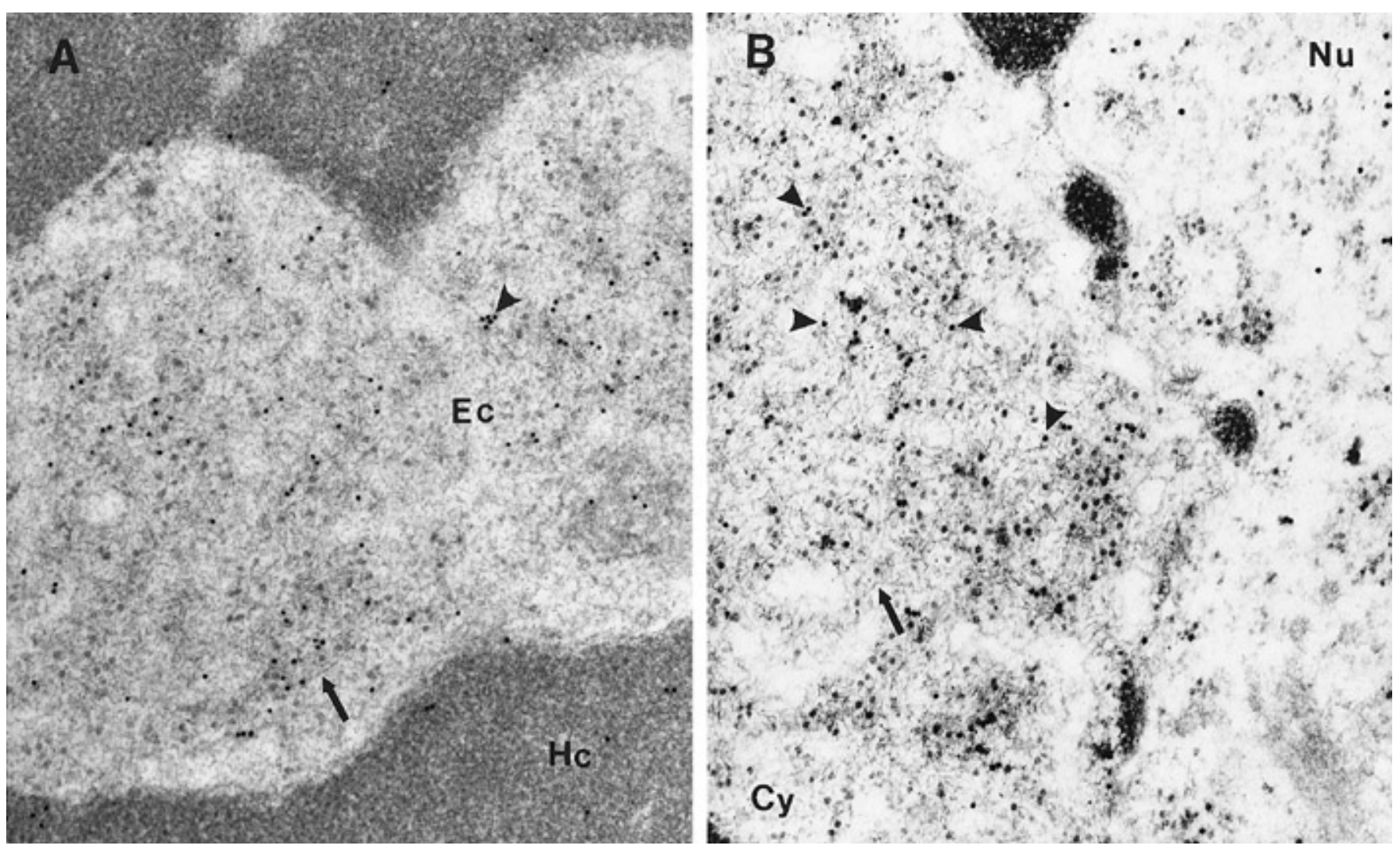

Fig. 2. Immunolocalization of the barley yellow dwarf virus strain PAV 17-kDa protein 2 to 4 days postinoculation. A, In nuclei of infected oat phloem cells, the 17-kDa protein (arrowhead indicates gold label) was commonly associated with filaments (arrow) in the nuclear euchromatin $(\mathrm{Eu})$. Hc $=$ heterochromatin. $\mathbf{B}$, In the cytoplasm (Cy), the 17-kDa protein (arrowheads indicate gold label) was most often associated with intermediate regions of filaments (arrow) and only rarely associated with filament termini. $\mathrm{Nu}=$ nucleus. $\mathbf{A}, \times 49,000 . \mathbf{B}, \times 48,000$. 
during all stages of the infection cycle. Before cross-adsorbing the $17-\mathrm{kDa}$ antiserum, some nonspecific labeling was observed over cell walls. After cross-adsorption, the polyclonal antibodies specifically labeled only infected plant samples. The $17-\mathrm{kDa}$ protein was observed as early as $1 \mathrm{dpi}$ in nuclei in association with euchromatin in infected cells (Fig. 2A). When the 17-kDa antiserum labeled filamentous material, gold particles were sometimes bound to one terminus of the filaments, but more often were found along the length of the filaments (Fig. 2B). Labeling with the 17-kDa antiserum was dependent on the presence of filaments and was detected in both the cytoplasm and the nucleus at 2 to 4 dpi (Fig. 1). The $17-\mathrm{kDa}$ protein occasionally was associated with filaments seen within nuclear pores (Fig. 3). Areas of condensed filamentous material often were labeled (Fig. 1). However, the label densities were higher over areas that contained free filaments and were higher than those produced using antibodies specific for virus particles (Table 1). Gold-label densities for the $17-\mathrm{kDa}$ protein were similar in the nucleus and the cytoplasm (Table 1). Labeling densities with the $17-\mathrm{kDa}$ antiserum was lower in the cytoplasm in areas with condensed filaments. The $17-\mathrm{kDa}$ protein was rarely associated with viral particles. In BYDV-infected cells at the late stage of infection, the condensed filamentous material was labeled (Fig. 4). The $17-\mathrm{kDa}$ protein was never seen associated with oat phloem plasmodesmata.

In situ hybridization. Both plus- and minus-strands of BYDVPAV RNA were detected throughout the infection cycle. Protease pretreatment was essential for successful in situ localization of viral nucleic acids (data not shown). Nonspecific labeling occasionally was seen in control samples over cell walls, mitochondria, and nuclear heterochromatin. In contrast, specific labeling was most often associated with filamentous material in the cytoplasm (Fig. 5), nucleus (Fig. 6), and virus-induced vesicles (Fig. 7). Labeling often occurred as rows of three or more gold particles (Fig. 5). Minusstrand RNA was detected first in the nucleus and slightly later in the cytoplasm (Fig. 6). Gold labeling from RNA probes was associated with filamentous material that could easily be discerned in conventionally fixed sections; for example, in vesicles (Fig. 7). Labeling was abundant in freeze-substituted sections, but filaments

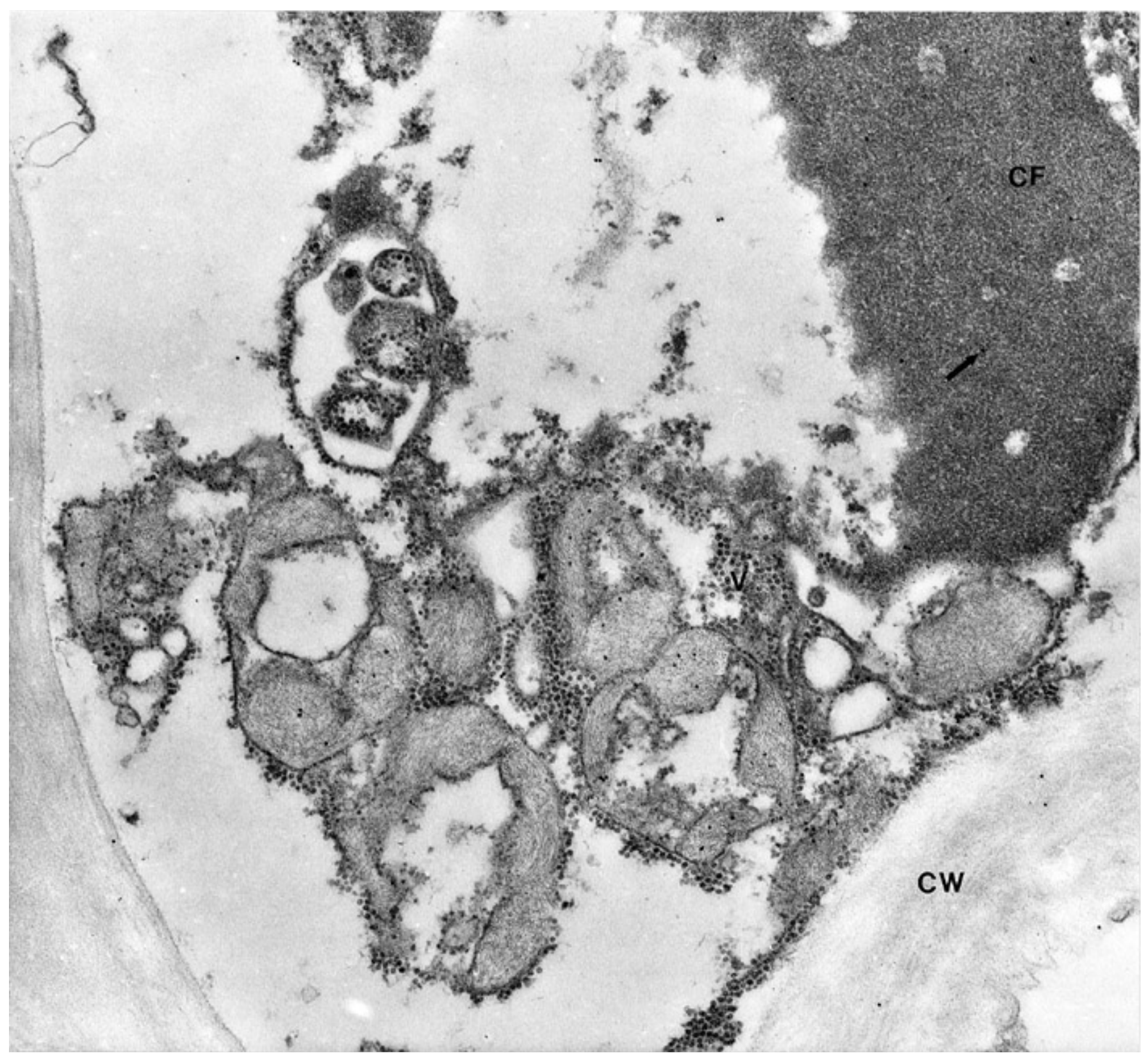

Fig. 4. In the late stage of barley yellow dwarf virus strain PAV infection in oat phloem cells ( 5 to 10 days postinoculation), the 17-kDa protein (arrow indicates gold label) was associated with condensed filaments (CF). Cells contained mainly degenerated organelles and viral particles $(\mathrm{V})$. CW $=$ cell wall. $\times 42,500$. 
were difficult to distinguish, so that the association of gold label with the filaments was not as easy to confirm (Fig. 8). During the late stage of infection ( $>5 \mathrm{dpi}$ ), areas that contained large amounts of condensed filaments were labeled with both viral RNA probes (Fig. 9). In contrast, areas of cells in the late stage that contained large numbers of virus particles contained predominantly plusstrand RNA (Fig. 10).

\section{DISCUSSION}

In this study, we localized the $17-\mathrm{kDa}$ protein and RNA of BYDV-PAV in infected oat cells. Both were associated with filamentous material in the cytoplasm and the nucleus. Because the BYDV-PAV biotin-label RNA probes specifically bound to the filamentous material in the in situ hybridization assay, we suggest that the filamentous material contains BYDV RNA. Nonspecific labeling in noninfected control samples was rare, further confirming the specificity of the assay. However, in situ hybridization with BYDVPAV probes was successful only after pretreatment of the ultrathin sections with protease $\mathrm{K}$, which suggests that viral RNA is associated with protein, possibly the $17-\mathrm{kDa}$ protein, BYDV $\mathrm{CP}$, host cellular proteins, or a combination of these proteins. This result is consistent with the observations of Gill and Chong (11-13), who were unable to remove the filaments by RNAse treatment and suggested that proteins bound to the viral nucleic acids might prevent RNA digestion.

Although filaments appeared typically in the cytoplasm before the nucleus, one sample showed abundant labeling of filaments in the nucleus, and filaments were absent from the cytoplasm. It is possible that, in this case, filament clusters in the cytoplasm were in an area that was not sectioned or accessible for viewing. Phloem cells are relatively long (several hundred micrometers) and filaments in the cytoplasm may have been absent in the few sections examined. In all other samples, filaments were seen only in the cytoplasm or in both the nucleus and cytoplasm.

The site of viral RNA replication could not be unequivocally determined, because localization of neither double-stranded (ds)

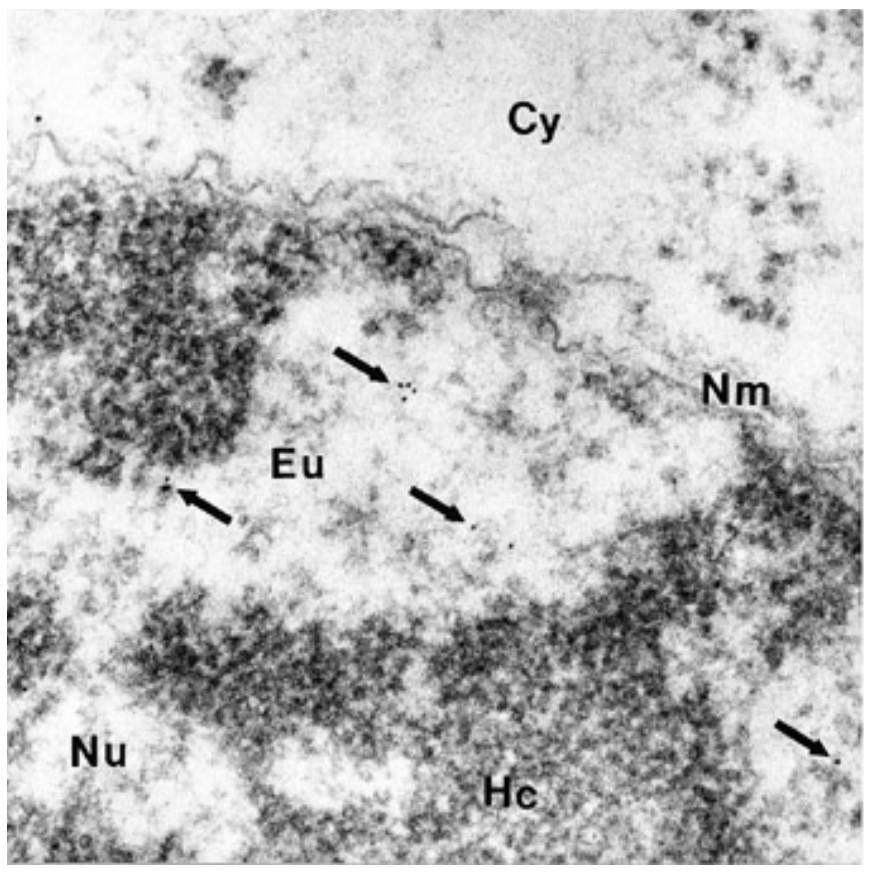

Fig. 6. In situ localization of barley yellow dwarf virus strain PAV plus-strand RNA in the nucleus of infected oat phloem cells at the early stage of infection (1 to 2 days postinoculation). Labeling (arrows) at the early stage was sparse, but often observed first in euchromatic regions $(\mathrm{Eu})$ of the nucleus $(\mathrm{Nu})$ and later in the cytoplasm $(\mathrm{Cy}) . \mathrm{Hc}=$ heterochromatin and $\mathrm{Nm}=$ nuclear membrane. $\times 85,000$.
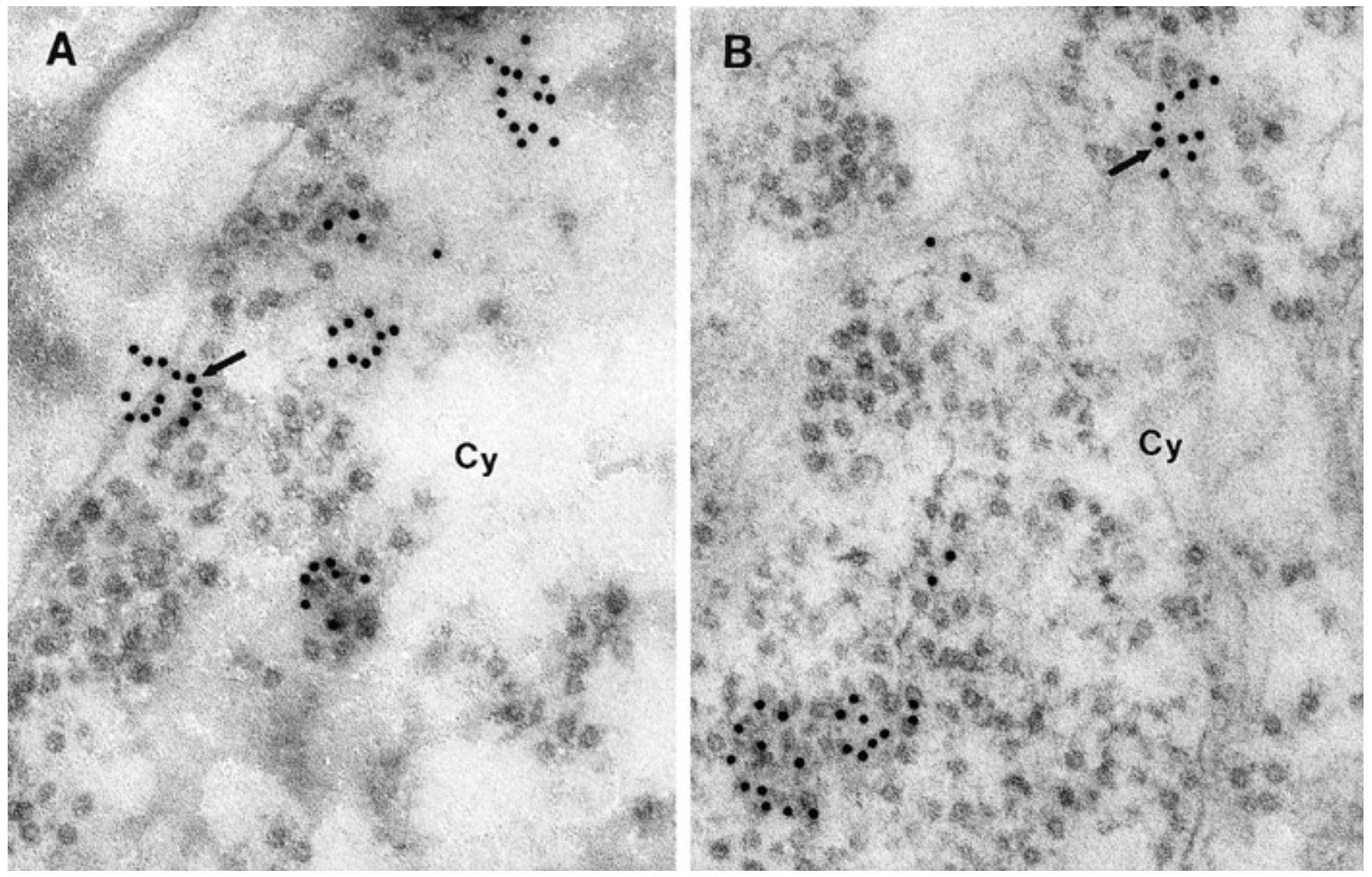

Fig. 5. Localization of barley yellow dwarf virus strain PAV plus- and minus-strand RNA in infected oat phloem cells 3 days postinoculation by in situ hybridization. A, Plus-strand and $\mathbf{B}$, minus-strand RNAs were both observed in the cytoplasm (Cy). Gold labeling often occurred in rows of three or more particles (arrows). A, $\times 122,400$. B, $\times 125,000$. 

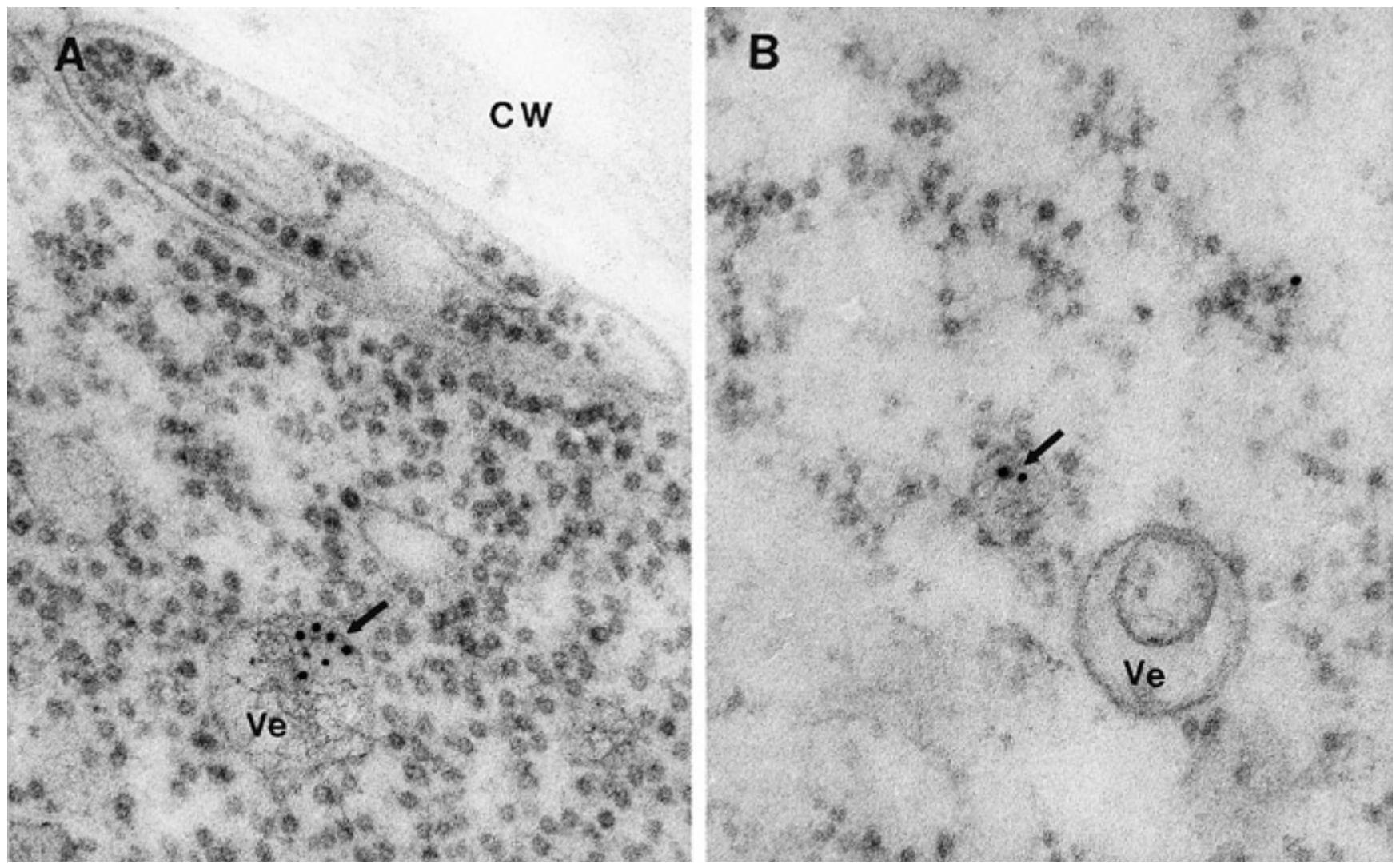

Fig. 7. In situ localization of barley yellow dwarf virus strain PAV plus- and minus-strand RNAs in conventionally fixed oat phloem cells 3 to 4 day postinoculation. A, Plus-strand and B, minus-strand RNAs (arrows indicate gold label) were often associated with filaments and sometimes seen in virus-induced vesicles (Ve). CW = cell wall. $\mathbf{A}, \times 111,000 . \mathbf{B}, \times 111,000$

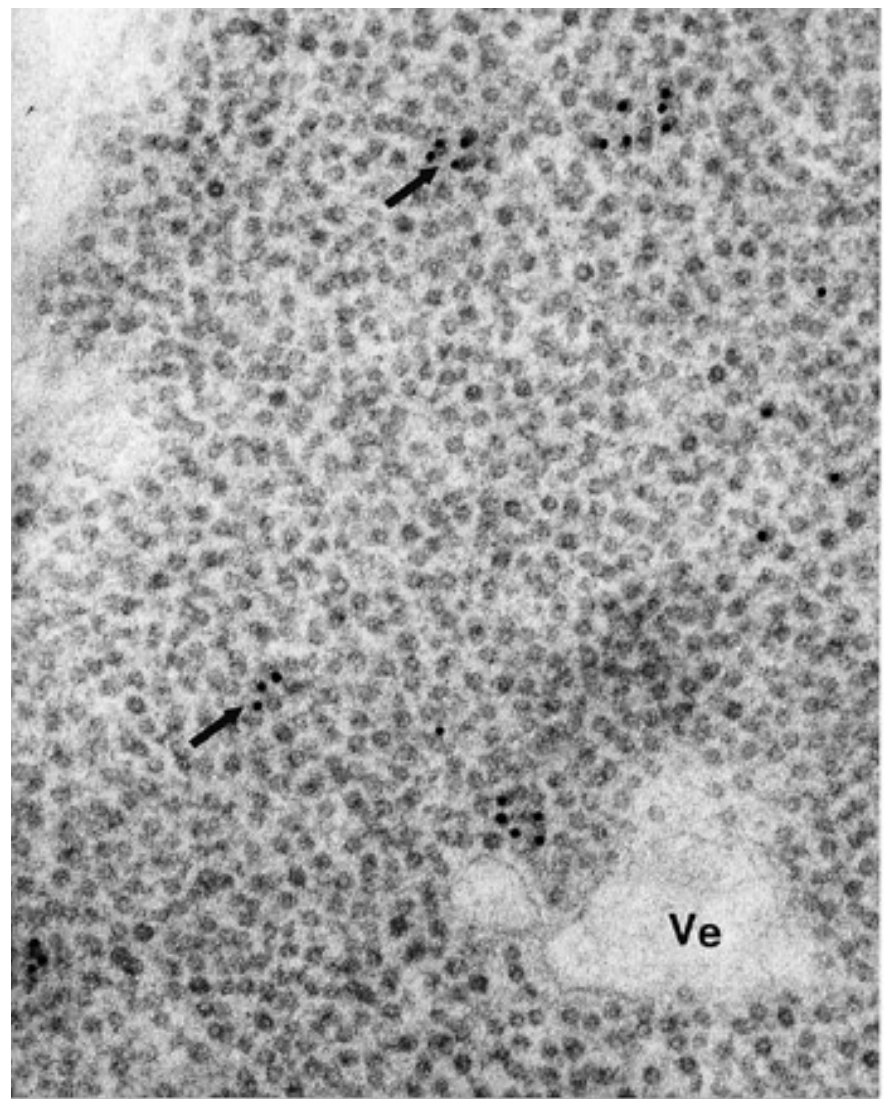

Fig. 8. In situ localization of barley yellow dwarf virus (BYDV)-PAV RNA in freezesubstituted cells. Labeling with BYDV-PAV minus-strand probes (arrows) was abundant in freeze-substituted cells. However, filaments, especially within vesicles (Ve), were more difficult to discern than in conventionally fixed sections (Fig. 7). ×84,000.
RNA nor viral replicase was undertaken. Negative-strand RNA was detected at early infection stages, first in the nucleus and slightly later in the cytoplasm. As reported previously (26), CP was not detected in infected cells until near the end of the intermediate stage of infection. Hence, RNA synthesis occurs before the accumulation of detectable amounts of $\mathrm{CP}$ and before virus particles are observed. The BYDV CP and 17-kDa protein are expressed from a subgenomic RNA that is thought to be transcribed from a negative-sense copy of the genomic RNA (22). The appearance of negative-sense RNA before CP and virus particles is consistent with this expression strategy. Minus- and plus-strand RNAs were associated with vesicular structures in the infected plant cells, and it is possible that virus-induced vesicles are involved in viral replication. In other RNA viruses, viral replication has been associated with membranous structures (2).

In previous analyses of the accumulation of plus- and minusstrand RNAs of plant viruses in protoplasts, minus-strand RNA synthesis was observed a few hours before plus-strand RNA accumulation was detected $(16,18,21)$. Minus-strand RNA accumulation ceased relatively early in infection, and the amount of minusstrand RNAs began to decrease. At the same time, the levels of plus-strand RNA increased rapidly and became stable late in infection. The localization of BYDV plus- and minus-strand RNAs in this study mirrors these findings. Both RNA strands were detected early in infection (Figs. 5, 7, and 9), but, near the end of the late stage of infection, plus-strand RNA was abundant, while minusstrand RNA was difficult to detect (Fig. 10).

The 17-kDa protein was associated with filamentous material in the cytoplasm and the nucleus. The densities of labeling were not significantly different in the nucleus and cytoplasm, unlike the labeling of the BYDV-PAV CP, which was observed primarily in the cytoplasm (26). Free filaments and groups of filaments in the nuclear pores were labeled occasionally by the $17-\mathrm{kDa}$ antiserum. Slightly lower labeling densities were observed over the condensed 

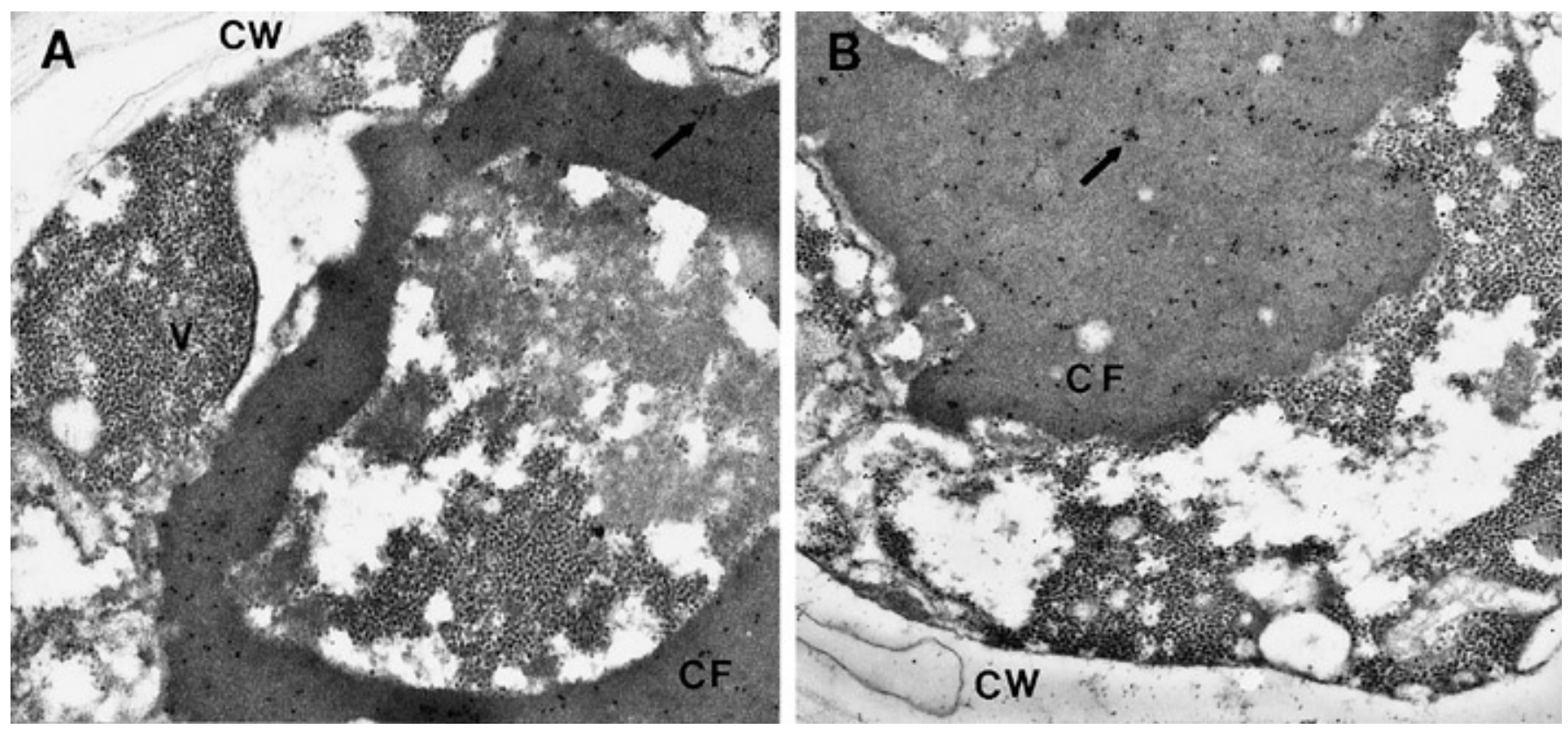

Fig. 9. In situ localization of barley yellow dwarf virus strain PAV RNA late in infection of oat phloem cells ( $>5$ days postinoculation). A, Plus-strand and B, minus-strand RNAs (arrows indicated gold label) were often associated with condensed filamentous material $(\mathrm{CF})$. $\mathrm{CW}=\mathrm{cell} \mathrm{wall}$ and $\mathrm{V}=\mathrm{viral}$ particles. $\mathbf{A}$, $\times 28,000 . \mathbf{B}, \times 28,000$.
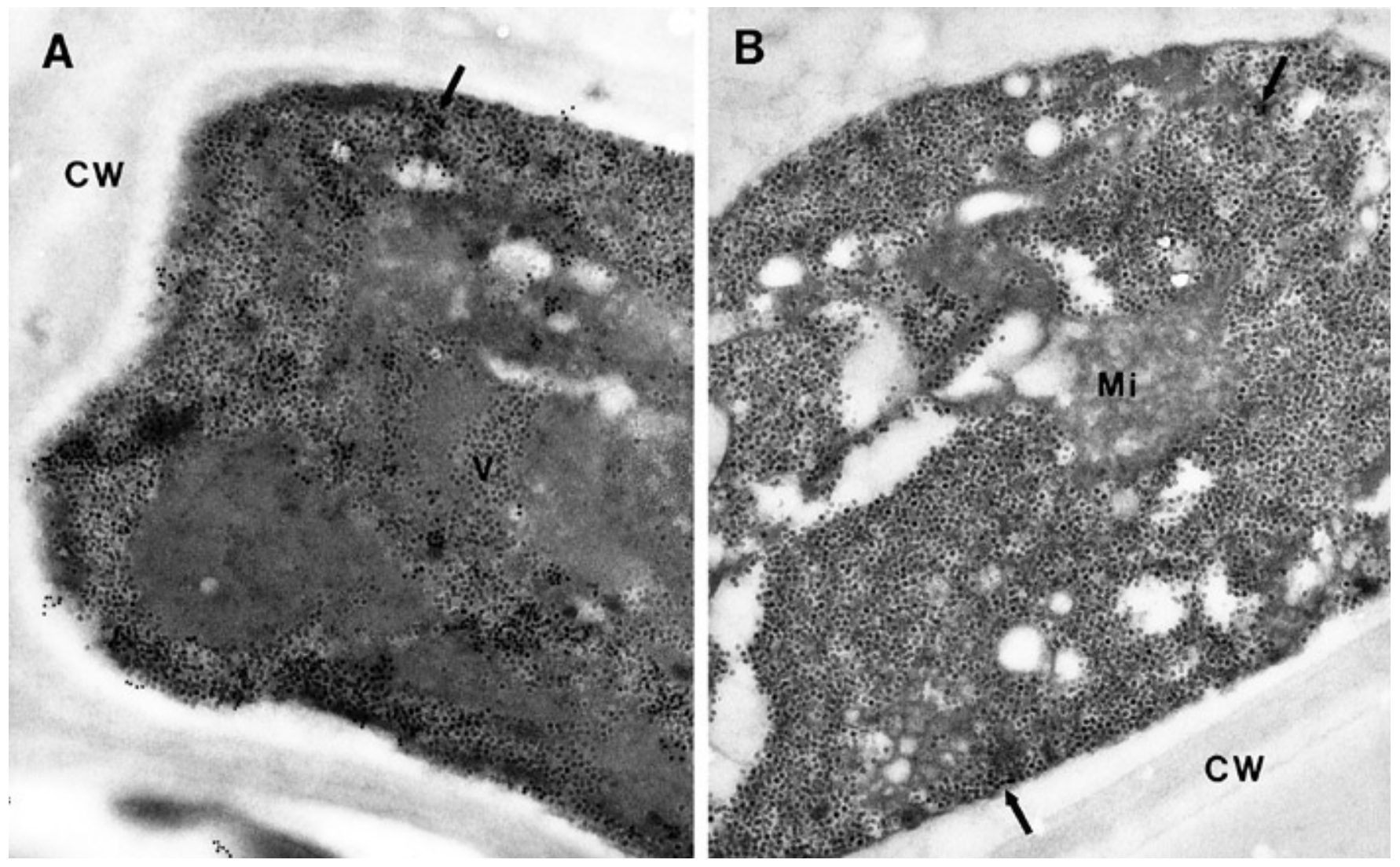

Fig. 10. In situ localization of barley yellow dwarf virus strain PAV RNA in the late stage of infection ( $>5$ days postinoculation) in oat phloem cells. A, Plus-strand RNA (arrow indicates gold label) was commonly detected in cells that were mostly filled with viral particles (V) and degenerated organelles such as mitochondria (Mi). B, Minus-strand RNA (arrows indicate gold label) was rarely observed in cells at this stage. CW $=$ cell wall. A, $\times 35,000$. B, $\times 35,000$.

filamentous material that was found most commonly at the late infection stages. The filaments in these areas may be degraded or may be composed predominantly of dsRNA, which does not bind the $17-\mathrm{kDa}$ protein efficiently. Interactions between the antibodies and the $17-\mathrm{kDa}$ protein in condensed filamentous material also may be sterically hindered. These results suggest that the filaments consist of viral ssRNA that is associated with $17-\mathrm{kDa}$ protein in vivo and are consistent with in vitro studies that reported that the 17-kDa protein of PLRV (pr17) possesses RNA-binding properties (35). It is possible that the $17-\mathrm{kDa}$ protein is required for movement of viral RNA across the nuclear membrane. However, the significance of the nuclear localization is uncertain given the 
observation that the $17-\mathrm{kDa}$ protein is not required for replication of BYDV-PAV RNA $(3,24)$.

The observation of the BYDV-PAV 17-kDa protein in the nucleus of infected cells agrees with the results of Tacke et al. (36), who found the PLRV 17-kDa protein associated with a subcellular fraction containing nuclei. Nuclear transport is usually a very selective process involving recognition of the protein by receptors in the nuclear pores and then the active transport of the protein across the nuclear membrane (32). The association of $17-\mathrm{kDa}$ protein on both sides of the nuclear envelope with filaments that extend through nuclear pores suggests that the $17-\mathrm{kDa}$ protein may contain amino acid sequences that are recognized as nuclear localization signals. The 22-kDa CP and the carboxyl terminus of the $17-\mathrm{kDa}$ protein contain basic amino acids that usually form nuclear localization signals. However, $\mathrm{CP}$ is not found in the nucleus until a very late stage, when the nuclear membrane is beginning to disintegrate (26). The accumulation of the $17-\mathrm{kDa}$ protein in the nucleus may be a by-product of its role in facilitating the movement of viral RNA across membranes. The observations of plus- and minus-sense BYDV-PAV RNA in association with membrane vesicles in the cytoplasm suggest that, like many RNA viruses, some steps of BYDV-PAV RNA replication occur in the cytoplasm. Other RNA viruses presumed to replicate in the cytoplasm (e.g., potyviruses) accumulate nonstructural proteins in the nucleus (29).

It had been proposed that the $17-\mathrm{kDa}$ protein could function as a VPg $(23,25)$. However, observations that mutations in the ORFs expressing the 17-kDa proteins of BWYV or BYDV-PAV did not affect replication of the viruses $(3,24,30)$ do not support this hypothesis. Labeling of filaments with $17-\mathrm{kDa}$ antibodies along their length, rather than only at termini, also fails to support the VPg hypothesis.

While luteoviruses and geminiviruses are capable of long-distance movement through vascular tissues, they usually cannot move laterally out of the vascular tissues. Schmitz et al. (31) localized pr17 in PLRV-infected and transgenic potato plants expressing the pr17 gene, which showed strong labeling of plasmodesmata (31) similar to that observed with the movement proteins of tobacco mosaic virus and alfalfa mosaic virus $(34,37)$. In sharp contrast, no labeling of plasmodesmata was observed with anti-17-kDa antiserum in this study. It is possible that the association between the 17-kDa protein and plasmodesmata, if one exists, may be more transient in BYDV-PAV-infected oat cells. BYDV-PAV-infected cells, like PLRV-infected cells, show rapid degradation of cellular structures and organelles. The association of the BYDV-PAV 17-kDa protein with plasmodesmata may have been overlooked in these highly disrupted cells, but, given the large number of samples examined, this seems unlikely. The cytopathological changes induced by luteoviruses (including BYDV-PAV) and poleroviruses (including BYDV-RPV and PLRV) are similar, but consistently different. For example, no filaments are observed in the nuclear pores or nuclei of oat cells infected with BYDV-RPV until very late in infection (12). These differences in cytopathology and labeling patterns may reflect functional differences in the mechanisms by which the proteins mediate movement of virus nucleic acids within cells, among cells, or both.

\section{LITERATURE CITED}

1. Atabekov, J. G., and Taliansky, M. E. 1990. Expression of plant viruscoded transport function by different viral genomes. Adv. Virus Res. 38: 201-248.

2. Buck, K. W. 1996. Comparison of the replication of positive-stranded RNA viruses of plants and animals. Adv. Virus Res. 47:159-251.

3. Chay, C. A., Gunasinge, U. B., Dinesh-Kumar, S. P., Miller, W. A., and Gray, S. M. 1996. Aphid transmission and systemic plant infection determinants of barley yellow dwarf luteovirus-PAV are contained in the coat protein readthrough domain and $17-\mathrm{kDa}$ protein, respectively. Virology 219:57-65.
4. Citovsky, V., Knorr, D., Schuster, G., and Zambryski, P. 1990. The P30 movement protein of tobacco mosaic virus is a single-strand nucleic acid binding protein. Cell 60:637-647.

5. de Zoeten, G. A., Assink, A. M., and van Kammen, A. 1974. Association of cowpea mosaic virus-induced double stranded RNA with a cytopathological structure in infected cells. Virology 59:341-355.

6. Esau, K. 1957. Phloem degeneration in Gramineae affected by the barley yellow dwarf virus. Am. J. Bot. 44:245-251.

7. Fouly, H. M., Domier, L. L., and D’Arcy, C. J. 1992. A rapid chemiluminescent detection method for barley yellow dwarf virus. J. Virol. Methods 39:291-298.

8. Gildow, F. E. 1987. Virus-membrane interactions involved in circulative transmission of luteoviruses by aphids. Curr. Top. Vector Res. 4: 93-120.

9. Gildow, F. E. 1993. Evidence for receptor-mediated endocytosis regulating luteovirus acquisition by aphids. Phytopathology 83:270-277.

10. Gildow, F. E., and Rochow, W. F. 1980. Role of accessory salivary glands in aphid transmission of barley yellow dwarf virus. Virology 104:97-108.

11. Gill, C. C., and Chong, J. 1975. Development of the infection in oat leaves inoculated with barley yellow dwarf virus. Virology 66:440-453.

12. Gill, C. C., and Chong, J. 1976. Differences in cellular ultrastructural alterations between variants of barley yellow dwarf virus. Virology 75:33-47.

13. Gill, C. C., and Chong, J. 1979. Cytopathological evidence for the division of barley yellow dwarf virus isolates into two subgroups. Virology 95:59-69.

14. Hatta, T., and Francki, R. I. B. 1978. Enzyme cytochemical identification of single-stranded and double-stranded RNAs in virus-infected plant and insect cells. Virology 88:105-117.

15. Hull, R. 1989. The movement of viruses in plants. Annu. Rev. Phytopathol. 27:213-240.

16. Ishikawa, M., Meshi, T., Ohno, T., and Okada, Y. 1991. Specific cessation of minus-strand RNA accumulation at an early stage of tobacco mosaic virus infection. J. Virol. 65:861-868.

17. Jensen, S. G. 1969. Occurrence of virus particles in the phloem tissue of BYDV-infected barley. Virology 38:83-91.

18. Kim, K. H., and Hemenway, C. 1996. The 5' nontranslated region of potato virus X RNA affects both genomic and subgenomic RNA synthesis. J. Virol. 70:5533-5540.

19. LaFleche, C., Bové, C., Dupont, C., Mouches, C., Astier, T., Garnier, M., and Bové, J. M. 1972. Site of viral RNA replication in the cells of higher plants: TYMV-RNA synthesis on the chloroplasts outer membrane system. Pages 43-71 in: Meet. Fed. Eur. Biochem., 8th. North-Holland Publishing, Amsterdam.

20. Lin, N.-S., and Langenberg, W. G. 1985. Spherical vesicles in proplastids of barley stripe mosaic virus-infected wheat cells contain doublestranded RNA. Virology 142:291-298.

21. Marsh, L. E., Huntley, C. C., Pogue, G. P., Connell, J. P., and Hall, T. C. 1991. Regulation of (+):(-)-strand asymmetry in replication of brome mosaic virus RNA. Virology 182:76-83.

22. Miller, W. A., and Rasochova, L. 1997. Barley yellow dwarf viruses. Annu. Rev. Phytopathol. 35:167-190.

23. Miller, W. A., Waterhouse, P. M., Kortt, A. A., and Gerlach, W. L. 1988. Sequence and identification of the barley yellow dwarf virus coat protein gene. Virology 165:306-309.

24. Mohan, B. R., Dineshkumar, S. P., and Miller, W. A. 1995. Genes and cis-acting sequences involved in replication of barley yellow dwarf virus-PAV RNA. Virology 212:186-195.

25. Murphy, J. F., D’Arcy, C. J., and Clark, J. M. J. 1989. Barley yellow dwarf virus RNA has a 5'-terminal VPg. J. Gen. Virol. 70:2253-2256.

26. Nass, P. H., Jakstys, B. P., and D'Arcy, C. J. 1995. In situ localization of barley yellow dwarf virus coat protein in oats. Phytopathology $85: 556-560$.

27. Noueiry, A. O., Lucas, W. J., and Gilbertson, R. L. 1994. Two proteins of a plant DNA virus coordinate nuclear and plasmodesmal transport. Cell 76:925-932.

28. Pascal, E., Sanderfoot, A. A., Ward, B. M., Medville, R., Turgeon, R., and Lazarowitz, S. G. 1994. The geminivirus BR1 movement protein binds single-stranded DNA and localizes to the cell nucleus. Plant Cell 6:995-1006.

29. Restrepo, M. A., Freed, D. D., and Carrington, J. C. 1990. Nuclear transport of plant potyviral proteins. Plant Cell 2:987-998.

30. Reutenauer, A., Ziegler-Graff, V., Lot, H., Scheidecker, D., Guilley, H., Richards, K., and Jonard, G. 1993. Identification of beet western yellows luteovirus genes implicated in viral replication and particle morphogenesis. Virology 195:692-699.

31. Schmitz, J., Stussi-Garaud, C., Tacke, E., Prufer, D., Rohde, W., and Rohfritsch, O. 1997. In situ localization of the putative movement protein (pr17) from potato leafroll luteovirus (PLRV) in infected and trans- 
genic potato plants. Virology 235:311-322.

32. Silver, P. A. 1991. How proteins enter the nucleus. Cell 64:489-497.

33. Smith, D. B., and Johnson, K. S. 1988. Single-step purification of polypeptides expressed in Escherchia coli as fusions with glutathione-S-transferase. Gene 67:31-40.

34. Stussi-Garaud, C., Garaud, J. C., Bema, A., and Godefroy-Colburn, T. 1987. In situ location of an alfalfa mosaic virus non-structural protein in plant cell walls: Correlation with virus transport. J. Gen. Virol. 68:1779-1784.

35. Tacke, E., Prufer, D., Schmitz, J., and Rohde, W. 1991. The potato leaf- roll luteovirus $17 \mathrm{~K}$ protein is a single-stranded nucleic acid-binding protein. J. Gen. Virol. 72:2035-2038

36. Tacke, E., Schmitz, J., Prifer, D., and Rohde, W. 1993. Mutational analysis of the nucleic acid-binding $17 \mathrm{kDa}$ phosphoprotein of potato leafroll luteovirus identifies an amphipathic alpha-helix as the domain for protein protein interactions. Virology 197:274-282.

37. Tomenius, K., Clapharn, D., and Meshi, T. 1987. Localization by immunogold cytochemistry of the virus-coded $30 \mathrm{~K}$ protein in plasmodesmata of leaves infected with tobacco mosaic virus. Virology 160:363-371. 